\title{
Optimizing the Authority of Indonesia Customs in Legal Protection of Intellectual Property Rights
}

\author{
Yoga Mahardhita ${ }^{\text {la }}$, Kholis Roisah $^{\text {lb }}$ \\ ${ }^{1}$ Faculty of Law, Universitas Diponegoro, Semarang, Indonesia \\ ayoga.mahardhita@gmail.com, ${ }^{\mathrm{b}}$ r_kholis@yahoo.com
}

\begin{abstract}
The Indonesian Government has issued Government Regulation Number 20 of 2017 which regulates the authority of customs in enforcing intellectual property rights. Although the legal framework for the protection of intellectual property rights has been strengthened, but the counterfeit and piracy of intellectual property rights related to imports are still high. This research is an empirical research by using method of socio-legal approach, which study law with approach of law science and social science. The results of the research show that the authority of the Directorate General of Customs and Excise in the enforcement of IPR can be done through the prevention of the position of the Customs and Excise Officer (ex-officio) or by the order of the Chief of the Court (Judicial). The Directorate General of Customs and Excise should optimize its authority in enforcing IPR through an ex-officio scheme because it will be more effective and reduce the time period of the bureaucracy. However, it requires challenges such as changes in legislation and capacity building of DGCE employees in the field of IPR.
\end{abstract}

Keywords-Customs; Intellectual Property Rights

\section{INTRODUCTION}

Violations of intellectual property rights (IPR) are a serious and growing threat to the health, safety and economic interests of the entire world. Counterfeit and pirated goods that infringe legitimate intellectual property rights are produced, transported, distributed or sold in every country throughout the world. The globalization of counterfeiting and piracy poses a very real and growing threat to both developed and developing countries. Counterfeiting and piracy are serious threats to consumer health and safety, tax revenue, and innovation that is essential to economic development. The impact of infringement on intellectual property rights are business loss, reduced taxation, lack of product innovation, loss of employment, low consumer protection and impact on public order since intellectual property rights violations are closely related to organized crime international (Blakeney, 2009)

Stimulant factors of infringement or counterfeiting are as follows (Citrawinda, 2013):

1. Technology progress in the field of industry;

2. Hard to control production activity;

3. Non-availability of producer data due to lack of control of machinery importation and the weak control of importation of raw material;

4. Significant price difference between legal products and illegal products;

5. Legal enforcement is not effective yet, even though Government commitment is sufficiently high;

6. Goods shipped from Indonesian harbors;
7. Indonesia has a distinct geographical nature consisting of more than 17,000 islands which creates another challenge to control its borders for potential IPR infringement.

Legal protection against IPR is an important factor for the state in promoting economic growth and is one form of state efforts in protecting its citizens from the dangers of counterfeit goods. The growing trade of the country beyond the borders of the country resulted in the awareness of the importance of protection against IPR, which later became the background of The TRIPs Agreement (Roisah, 2015). In the TRIPs agreement, the issue of law enforcement is of concern in providing protection to intellectual property rights. One of the institutions granted authority in law enforcement is customs authority as stated in Part III of Enforcement of Intellectual Property Rights, especially in Section 4: Special Requirements Related To Border Measures, consisting of 10 (ten) articles, Article 51 to Article 60.

Customs authority in enforcing infringement of Intellectual Property Rights is considered important because it has the following potential (Sutedi, 2012):

1. position at the gates and borders of the territory of the state, so as to effectively prevent and deter the goods allegedly infringing Intellectual Property Rights into free circulation.

2. authority to prevent goods, seizure of goods, conduct physical inspection of goods and related documents.

3. the ability of intelligence or information owned then it can identify and handle until the source from which the infringing goods come from. 
4. cooperation among customs authorities in various countries in the World Customs Organization (WCO), thus facilitating enforcement of intellectual property infringement.

The authority of the customs authorities in TRIPs is also adopted into Indonesian legislation as a manifestation of the commitment and consequences of Indonesia which signed the agreement on the establishment of the World Trade Organization (WTO) through Law No. 7 of 1994 on the ratification of the Agreement Establish the World Trade Organization. The authority of the customs authority is regulated in Articles 54 through Article 64 of Law Number 10 of 1995 concerning Customs as amended by Law No. 17 of 2006.

Furthermore, in 2017, after approximately 20 years since the Customs Act was issued, Indonesia finally issued Government Regulation No. 20 of 2017 concerning Control of Import or Export of Goods Suspected of or Derived from the Result of Violation of Intellectual Property Rights as a rule of law enforcement implementation intellectual property by customs authorities in this case the Directorate General of Customs and Excise, which became effective on August 2, 2017.

During the period prior to the issuance of Government Regulation No. 20 of 2017, the enforcement of intellectual property rights by customs authorities refers to Supreme Court Regulation Number 4 of 2012 on Temporary Suspension. However, the Supreme Court Regulation did not run effectively and optimal considering the scope of its regulation is limited to the Supreme Court Regulation. This situation brought loss of Rp. 65 trillion and the loss of income from indirect tax on the sale of original software up to Rp. 424 billion. In addition, Indonesia is also a country with a priority watch list category after China in special report 3012018 by United States Trade Representative (USTR, 2018).

\section{RESEARCH METHOD}

Research in general aims to find develop or test the truth of a knowledge. Finding means trying to get something to fill in the gaps or deficiencies. Developing means expanding and digging deeper into something that exists. Testing the truth is done if what already exists is still or doubted to be true. Research method in this thesis use empirical research method. Empirical research or field research is a research based on experience, both the experience itself and the experience of others (Frick, 2012).

Method The research approach used in this thesis is Socio Legal. Socio-legal research is a study of law by using the approach of law science and social sciences. In principle, socio-legal studies are legal studies, which use the approach of social science methodology in a broad sense. The word "socio" in socio-legal studies presents the interrelationships between the contexts in which the law exists (Irianto, 2011)

\section{RESULT AND DISCUSSION}

\section{A. The authority of the Directorate General of Customs and Excise in the Enforcement of Intellectual Property Rights}

The implementation of IPR enforcement in border area by customs agency in The TRIPs Agreement is regulated in Part III of Enforcement of Intellectual Property Rigts, especially in Section 4: Special Requirements Related To Border Measures, consisting of 10 (ten) articles (Article), namely Article 51 to with Article 60. The provisions relating to the authority of customs agencies themselves are provided for in Article 51 and Article 58. Article 51 TRIPs states that:

"Members shall, in conformity with the provisions set out below, adopt procedures to enable a right holder, who has valid grounds for suspecting that the importation of counterfeit trademark or pirated copyright goods may take place, to lodge an application in writing with competent authorities, administrative or judicial, for the suspension by the customs authorities of the release into free circulation of such goods. Members may enable such an application to be made in respect of goods which involve other infringements of intellectual property rights, provided that the requirements of this Section are met. Members may also provide for corresponding procedures concerning the suspension by the customs authorities of the release of infringing goods destined for exportation from their territories."

Article 51 of the above TRIPs in principle instructs each Member State to apply procedures which permit rightsholders / holders of the right, with sufficient evidence or valid reasons for alleged importation of counterfeit goods (fake brands) or pirated copyrights, submit a written application to the competent authority, whether administratively or judicially, to suspend / release goods to free circulation through the customs authority. Each Member State may also permit the same application in respect of any other infringement of IPR (other than trademark and copyright), in accordance with the necessary conditions. Member countries may also provide suspended procedures for the release of export goods suspected of infringement of IPR by the customs authorities.

Unlike Article 51, Article 58 TRIPs instructs each member country in case it is necessary to authorize competent agencies (in this case customs agencies) on their own initiative to enforce IPR enforcement by suspending the expenditure of goods from the Customs Area on the basis of sufficient evidence. The authority of the customs agency listed in Article 58 is often referred to as an ex-officio action.

The authority of IPR enforcement in the border area by customs agencies as set forth in Section 4: Special Requirements Related To Border Measures The TRIPS Agreement is also adopted in the national legal instrument as a manifestation of Indonesia's participation in the membership of the World Trade Organization and the World Intellectual Property Organization (WIPO). The authority of IPR enforcement in border areas in Indonesia 
run by the Directorate General of Customs and Excise is regulated in Law Number 10 of 1995 concerning Customs as amended by Law Number 17 of 2006, particularly in Articles 54 to 64 .

Article 54 of the Customs Law states that "At the request of the owner or holder of the rights to the mark or copyright, the head of the commercial court may issue a written order to the customs and excise authority to temporarily suspend the release of imported or exported goods from a customs zone on the basis of sufficient evidence, copyrighted works in Indonesia ".

The action as stipulated in Article 54 is often referred to as a judicial action scheme, since the initiative comes from the owner or right holder to the Chairman of the Commercial Court. While the regulation of DGCE's actions by ex-officio itself is regulated in Article 62 of the Customs Law, which states:

"The act of suspending the release of imported or exported goods may also be made due to the iniciative of the Customs Officer if there is sufficient evidence that the goods are or derived from a violation of the mark or copyright."

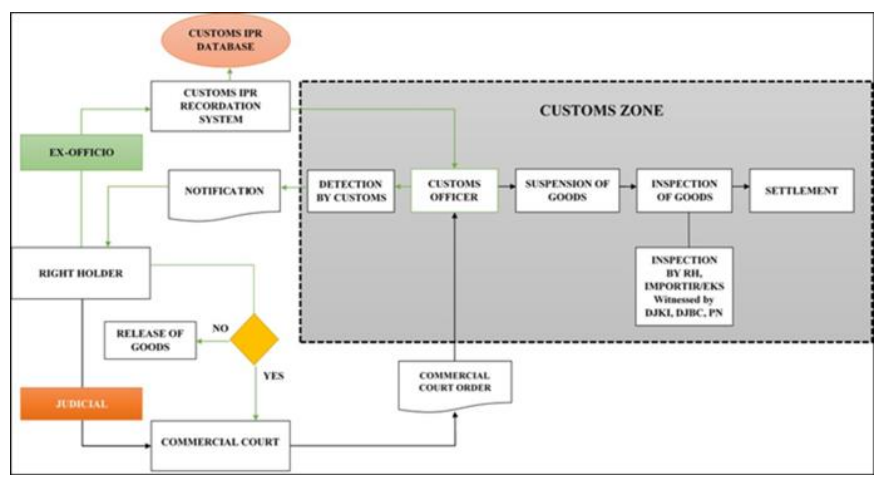

Fig. 1. Indonesia Customs Enforcement in Legal Protection of IPR.

To obtain ex-officio protection, the owner or right holder must be a business entity and must file a record of brand and copyright to the Directorate General of Customs and Excise along with documentary evidence such as photocopy of deed of establishment, photocopy of Taxpayer Identification Number (NPWP), copy of domicile letter, and photocopy of brand certificate and guarantee of Rp. 100 million in operational cost (handling cost). In the ex-officio protection mechanism required an examiner appointed by the Owner or the right holder in charge of communicating with customs officers.

Based on the results of sufficient recording and proof, the Directorate General of Customs and Excise shall make a prejudice against the goods allegedly infringing intellectual property rights. On the basis of such deterrence the Directorate General of Customs and Excise shall notify the Owner or right holder through the examiner to provide an opportunity for further legal action. In the event of further legal action, the Owner or right holder must submit a request to the Commercial Court Chairman to instruct the Directorate General of Customs and Excise to suspend the goods allegedly infringing intellectual property rights.

Unlike the ex-officio mechanism, a judicial suspension mechanism may be executed directly by the Owner or right holder by applying to the Head of the Commercial Court to order the Directorate General of Customs and Excise to suspend goods allegedly infringing intellectual property rights accompanied by documents required and warranty in accordance with the value of the goods.

The period of suspension conducted by the Directorate General of Customs and Excise is for 10 (ten) days and can be extended for 10 (ten days). Termination of suspension may be made if the period of suspension is exceeded, there is an order of the court chairman as well as legal action (seizure by investigator or bailiff) and other actions (agreement of dispute resolution outside court).

Although the enforcement provisions of IPR enforcement have been regulated in legislation clearly, but in the implementation there are still constraints that cause the implementation of IPR enforcement by DGCE is not optimal. One theory that can be used to analyze the effectiveness and constraints of IPR enforcement by DGCE is Lawrence M. Friedman's Theory of Law Systems which reveals that three elements of the legal system consist of legal structure, legal substance, and legal culture (Friedman, 2017). The legal structure is closely related to the functions of an institution that enforces IPR enforcement legislation in customs, in this case is an employee of DGCE especially in the field of law enforcement. The lack of knowledge of DGCE employees in the field of IPR becomes the main obstacle in the enforcement of IPR, especially Government Regulation No. 20 of 2017 and Regulation of the Minister of Finance No. 40 / PMK.04 / 2018 which regulates the technical action of DGCE employees in enforcing IPR is new, dissemination. Coordination between agencies such as the Commercial Court or the Directorate General of Intellectual Property Rights is also a challenge within the 'legal structure'.

The substance of the law concerning the material and the content or form of legislation. If viewed from the legislation that regulates the authority of DGCE in IPR enforcement namely PP Control of IPR and PMK 40 / PMK.04 / 2018, then there are some issues as follows:

1. The requirement of the form of 'business entity in Indonesia' in the recording mechanism to obtain exofficio protection as regulated in Article 5 paragraph (3) of Government Regulation No. 20 of 2017 is not in line with the provisions of Article 2 paragraph 3 of Paris Convention, which does not require the obligation of domicile in the protection of law enforcement in a country. Based on the results of the interview it is found that the consideration of the form of business entity with domicile in Indonesia is in order to support and encourage investment increase in Indonesia. However, the requirement of 'business entities in Indonesia' to be a special constraint on brand holders who are only in the form of representatives only, while proof of ownership still use the parent 
company.

2. Terms of guarantee of Rp. 100 million which is used as handling cost to DGCE causes reluctance of owner or holder of the brand to make suspension request, because the value is considered big.

3. The DGCE's authority mechanism in ex-officio deferral still requires an order from the Commercial Court Chief that adds to the length of the bureaucracy, especially now the number of Commercial Courts is only 5 (five) throughout Indonesia, namely Jakarta, Semarang, Surabaya, Makassar, and Medan.

The legal culture (Legal Culture) is a general emphasis of culture, habits, opinions, ways of acting and thinking, which direct social forces in society. The stigma in society that considers legal path is something that burdensome cost and longtime becomes an external constraint in IPR enforcement.

\section{B. Optimizing the authority of the Directorate General of Customs and Excise in Enforcement of Intellectual Property Rights}

The practice of law enforcement in developed countries is often a reference in applying the principles of IPR enforcement, one of which is Japan and China. Japan as a developed country, is very concerned about the issue of "law enforcement on Intellectual Property Rights". Similarly, China has similarities with aspects of Indonesia. China is the country with the highest rates of enforcement is also tailored to the characteristics of each country, such as Singapore which is the country with the largest transhipment, the enforcement of IPR also includes transit goods other than import and export. The authority of the customs agency in handling the enforcement of IPR also varies which includes the authority to decide whether there is a violation of IPR up to exterminate in case of proven violation of IPR. Clearly the authority of each country customs agency can be seen in the matrix of the match as on the Table 1 .

Optimization is an action, process or methodology for creating something (as a design, system, or decision) to be more perfect, functional, or more effective. Optimizing in the context of IPR enforcement is closely related to the way that the actions undertaken by the Directorate General of Customs and Excise as a watchdog of goods traffic are optimal and effective.

In order to strengthen the legal basis of the authority of the Directorate General of Customs and Excise in the protection of intellectual property rights, the Government has stipulated Government Regulation No. 20 of 2017 which regulates the technical implementation of law enforcement on intellectual property rights at the border. Although the provisions on the implementation of the authority of the Directorate General of Customs and Excise in Government Number 20 of 2017 are in accordance with the standards set out in the TRIPs, the implementation is still not optimal because there are still many cases of copyright and trademark infringement that

Tab. 1 Comparison of IPR Enforcement

\begin{tabular}{|c|c|c|c|c|c|c|c|c|c|c|}
\hline \multirow[b]{2}{*}{ Country } & \multirow[b]{2}{*}{ Import } & \multirow[b]{2}{*}{ Eksport } & \multirow{2}{*}{$\begin{array}{c}\text { Tranship } \\
\text { ment }\end{array}$} & \multirow[b]{2}{*}{ Type of IPR } & \multicolumn{3}{|c|}{ Procedure } & \multicolumn{3}{|c|}{ Authority } \\
\hline & & & & & Recordation & ex-officio & \begin{tabular}{|c|} 
Application from \\
$\mathrm{RH}$
\end{tabular} & decision & confiscation & extermination \\
\hline Japan & $\sqrt{ }$ & $\sqrt{ }$ & $\sqrt{ }$ & All type of IPR & $\sqrt{ }$ & $\sqrt{ }$ & $\sqrt{ }$ & $\sqrt{ }$ & $\sqrt{ }$ & $\sqrt{ }$ \\
\hline China & $\sqrt{ }$ & $\sqrt{ }$ & $\sqrt{ }$ & \begin{tabular}{|l|} 
Trademark, Copyrights, \\
Exclusive Olympic \\
Rights and symbol
\end{tabular} & $\sqrt{ }$ & $\sqrt{ }$ & $\sqrt{ }$ & $\sqrt{\text { or court }}$ & $\sqrt{ }$ & $\sqrt{ }$ \\
\hline Malaysia & $\sqrt{ }$ & - & - & Trademark \& Copyrights & - & $\sqrt{ }$ & $\sqrt{ }$ & - & - & - \\
\hline Singapore & $\sqrt{ }$ & $\sqrt{ }$ & $\sqrt{ }$ & Trademark \& Copyrights & - & $\sqrt{ }$ & $\sqrt{ }$ & $\sqrt{ }$ & $\sqrt{ }$ & $\sqrt{ }$ \\
\hline Thailand & $\sqrt{ }$ & $\sqrt{ }$ & $\sqrt{ }$ & Trademark \& Copyrights & $\sqrt{ }$ & $\sqrt{ }$ & $\sqrt{ }$ & $\sqrt{ }$ & $\sqrt{ }$ & $\sqrt{ }$ \\
\hline Vietnam & $\sqrt{ }$ & $\sqrt{ }$ & - & $\begin{array}{l}\text { Trademark, Copyrights } \\
\text { \& geographical } \\
\text { indication }\end{array}$ & $\sqrt{ }$ & $\sqrt{ }$ & $\sqrt{ }$ & $\sqrt{ }$ & $\sqrt{ }$ & $\sqrt{ }$ \\
\hline Indonesia & $\sqrt{ }$ & $\sqrt{ }$ & - & Trademark \& Copyrights & $\sqrt{ }$ & $\sqrt{ }$ & $\sqrt{ }$ & - & - & - \\
\hline
\end{tabular}

counterfeiting and piracy in the world, and is even ranked in the first order priority watch list by USTR.

Nevertheless, China has done a lot of improvements in the enforcement of IPR especially through the role of Chinese customs authorities that can increase from year to year. The implementation of IPR enforcement in customs circles conducted by several other ASEAN countries can also be used as a reference in the effort of optimizing the authority of DGCE in the enforcement of IPR.

Based on the study of laws in Japan, China, Malaysia, Singapore, Thailand, and Vietnam it is known that each country has a legal instrument that regulates IPR law enforcement related to border measures. The scope of IPR should be prevented through mechanism suspension by the Directorate General of Customs and Excise.

Several factors causing less optimal protection of intellectual property rights by the Directorate General of Customs and Excise are among others:

1. Although Government Regulation No. 20 of 2017 has been enacted on June 2, 2017 and shall become effective 60 (sixty) days after the date of promulgation on August 1, 2017, but until now it is still unworkable due to lack of facilities and infrastructure such as a recording system (recordation). 
2. None of the rights holders who have applied for suspension due to the lack of socialization of regulations.

3. The lack of knowledge of customs and excise officers on the authenticity of the product.

4. Not optimal synergy and coordination among law enforcers, such as the Indonesian Police and DJKI.

5. In carrying out the suspension of import or export goods suspected of infringement of Intellectual Property Rights in the ex-officio scheme (due to position) by the Directorate General of Customs and Excise still require orders from the Commercial Court. This causes the regulation to be ineffective because the Commercial Court in Indonesia is currently only 5 (five) namely Medan, Jakarta, Semarang, Surabaya and Makassar.

Indonesia Customs plays an important role in preventing goods infringement of intellectual property rights of Customs area because the Directorate General of Customs and Excise is the gateway to enter a country so that the protection of intellectual property rights will be more effective and optimal if the Directorate General of Customs and Excise is able to optimize function of exofficio protection.

If the optimization of the authority of the Directorate General of Customs and Excise in the protection of intellectual property rights is viewed from a legal system of intellectual property protection, then the legal system theory approach of Lawrence M. Friedman which proposes three elements of the legal system consisting of legal structure, legal susceptibility, and legal culture. The legal structure is closely related to the officer or law enforcement, the legal substance in relation to the prevailing laws and regulations which have binding powers and serve as legal guidelines and legal culture which are human attitudes (including the legal culture of its law enforcement apparatus) to the law and the legal system.

The legal structures that exercise intellectual property protection in the border areas are customs and excise officers. Legal protection can be achieved optimally if customs and excise officers have the ability to at least collect sufficient evidence to perform active action procedures. Ongoing internal dissemination and dissemination as well as coordination with other agencies such as civil servant investigators at the Directorate General of Intellectual Property Rights and the Indonesian Police are absolutely necessary to support the enforcement of intellectual property infringement. In addition, the integrity of employees in the enforcement of intellectual property rights is also an important factor.

The substance of the law concerning the material and the content or form of legislation. In case of further review, revitalization of ex officio authority in Government Regulation No. 20 of 2017 is necessary. This is because according to the provisions of the Government Regulation, ex-officio scheme (due to position) by the Directorate General of Customs and Excise still require orders from the Commercial Court, which currently still needs to be tested to reach all customs areas in Indonesia.
In addition, the form requirement of a Business Entity (Badan Usaha) for the holder of the right to file a recording may be deemed to be contrary to Article 2 paragraph 3 of the Paris Convention, which states

"However, no requirement as to domicile or establishment in the country where protection is claimed may be imposed upon nationals of countries of the Union for the enjoyment of any industrial property rights".

The most important element in the legal system of intellectual property protection is the legal culture. The culture of law is the emphasis of the cultural side in general, the habits, opinions, ways of acting and thinking, which direct the social forces in society. The negative public stigma of law enforcement that tends to be wasteful and ineffective becomes a challenge in enforcing violations of intellectual property rights. In addition, the cultural organization of customs agencies of Indonesia which prioritizes the function of state revenue will be an obstacle in achieving the enforcement of intellectual property rights violations are effective and optimal.

In accordance with the legal system theory proposed by Lawrence M. Friedman, the law will play well when the three sub-aspects of structure, substance, and legal culture interact and play a role in accordance with its function, so that the law will run in harmony and balance, accordingly with its function. If the three legal subsystems are not functioning properly, then there will be problems in the effort to function the law as a means of renewal and development of society itself.

\section{CONCLUSION}

The protection of intellectual property law in the border area is necessary in order to prevent the circulation of goods infringing intellectual property rights into trade routes that may harm the interests of the wider community. In carrying out its function as a traffic controller of goods, the Directorate General of Customs and Excise as an Indonesian customs agency is given the authority to protect intellectual property rights especially in border areas.

The authority of the Directorate General of Customs and Excise in the protection of intellectual property rights shall be conducted through two mechanisms, namely the exofficio or judicial suspension through the commercial court. The function of authority in the protection of intellectual property rights has not been optimal yet in line with the increasing violation of intellectual property rights from year to year. The optimization of the authority of the Directorate General of Customs and Excise in the protection of intellectual property rights can be done immediately to the effectiveness of an ex-officio exemption mechanism, with some notes as future evaluations such as enhancing customs and excise duties in the field of intellectual property rights, on an ongoing basis with the relevant apparatus, revitalizing ex-officio authority in legislation so as to be able to conduct direct grant without requiring orders from the Commercial Court and lastly by continuously socializing the regulation both internally and externally. 


\section{REFERENCES}

[1] Michael Blakeney, "International Proposals for the Criminal Enforcement of Intellectual Property Rights: International Concern with Counterfeiting and Piracy", Queen Mary University of London, Legal Research Paper, No. 29, 2009, page.6-11.

[2] Cita Citrawinda, "IP Law Enforcement Issues in Indonesia From A Practical Perspective", Seminar FAMI The 9th Intellectual Property Rights in Jakarta, February, 25, 2013.

[3] Adrian Sutedi, “Aspek Hukum Kepabeanan", Jakarta: Sinar Grafika, 2012, page. 315.

[4] Lawrence M. Friedman, "American Law: In Itroduction", Third Edition, New York: Oxford University Press, 2017, page. 5-13.

[5] Heinz Frick, "Pedoman Karya Ilmiah", Yogyakarta: Kanisius, 2012, page. 24

[6] Sulistyowati Irianto, "Metode Penelitian Hukum Konstelasi dan Refleksi”, Jakarta: Yayasan Obor Indonesia, 2011, page 175

[7] Richard A. Posner, "Economic Analysis of Law", USA: Harvard University Press, 1994, page 4,

[8] Richard A. Posner, "Utilitarianism, Economics, and Legal Theory", Journal of Legal Studies, Harvard Law Review, 1979, page 475 